\title{
Organoids: a promising new in vitro platform in livestock and veterinary research
}

\author{
Soumya K. Kar ${ }^{1 *} \mathbb{D}$, Jerry M. Wells ${ }^{2}$, Esther D. Ellen ${ }^{1}$, Marinus F. W. te Pas ${ }^{1}$, Ole Madsen³, Martien A. M. Groenen ${ }^{3}$
} and Henri Woelders ${ }^{1}$

\begin{abstract}
Organoids are self-organizing, self-renewing three-dimensional cellular structures that resemble organs in structure and function. They can be derived from adult stem cells, embryonic stem cells, or induced pluripotent stem cells. They contain most of the relevant cell types with a topology and cell-to-cell interactions resembling that of the in vivo tissue. The widespread and increasing adoption of organoid-based technologies in human biomedical research is testament to their enormous potential in basic, translational- and applied-research. In a similar fashion there appear to be ample possibilities for research applications of organoids from livestock and companion animals. Furthermore, organoids as in vitro models offer a great possibility to reduce the use of experimental animals. Here, we provide an overview of studies on organoids in livestock and companion animal species, with focus on the methods developed for organoids from a variety of tissues/organs from various animal species and on the applications in veterinary research. Current limitations, and ongoing research to address these limitations, are discussed. Further, we elaborate on a number of fields of research in animal nutrition, host-microbe interactions, animal breeding and genomics, and animal biotechnology, in which organoids may have great potential as an in vitro research tool.
\end{abstract}

Keywords: Animal health, Animal breeding and genomics, Animal nutrition, Host-microbe interaction, In vitro model, Organoids, Stem cell research, Veterinary research

\section{Table of Contents}

1 Introduction

2 Organoid derivation and culture methods

3 Research in major livestock and companion animals

3.1 Tissue-explants and re-aggregated dissociated cells

3.2 Stem cell-derived organoids in livestock and companion animals
3.2.1 Pig
3.2.2 Chicken
3.2.3 Cattle
3.2.4 Sheep

\subsubsection{Dog \\ 3.2.6 Cat \\ 3.2.7 Horse}

4 Potential improvements of organoid culture systems in livestock and veterinary research

4.1 High throughput, low cost, reproducible organoid platforms

4.2 2D organoid platforms

4.3 Collection of tissue samples; biopsies

4.4 Validation

4.5 Development of more complex systems

5 Potential uses of organoids in livestock and veterinary research

5.1 Fundamental biology and pathology

5.2 Nutritional research

5.3 Breeding
*Correspondence: soumya.kar@wur.nl

${ }^{1}$ Wageningen Livestock Research, Wageningen University \& Research, Wageningen, The Netherlands

Full list of author information is available at the end of the article

(C) The Author(s) 2021. This article is licensed under a Creative Commons Attribution 4.0 International License, which permits use, sharing, adaptation, distribution and reproduction in any medium or format, as long as you give appropriate credit to the original author(s) and the source, provide a link to the Creative Commons licence, and indicate if changes were made. The images or other third party material in this article are included in the article's Creative Commons licence, unless indicated otherwise in a credit line to the material. If material is not included in the article's Creative Commons licence and your intended use is not permitted by statutory regulation or exceeds the permitted use, you will need to obtain permission directly from the copyright holder. To view a copy of this licence, visit http://creativeco mmons.org/licenses/by/4.0/. The Creative Commons Public Domain Dedication waiver (http://creativecommons.org/publicdomain/ zero/1.0/) applies to the data made available in this article, unless otherwise stated in a credit line to the data. 


\subsection{Routine testing}

6 Conclusion

\section{References}

\section{Introduction}

In the first decade of the present century, it was shown that stem cells grown in vitro with required growth and differentiation factors in the presence of extracellular matrix (ECM) components can proliferate while maintaining "stemness", the ability to self-renew and give rise to self-organizing three dimensional (3D) structures $[1,2]$. While the term "organoids" has been used in the literature for decades, the feature of stem cell-based self-renewal and self-organization of multicellular (3D) structures containing multiple organ-specific cell in a manner similar to in vivo is used to define "organoids" in most current studies [3, 4]. Organoids can be generated from adult stem cells (ASCs) [2]; embryonic stem cells (ESCs) [1]; or from induced pluripotent stem cells (iPSCs), i.e. stem cells generated by "reprogramming" differentiated somatic cells (e.g. skin fibroblasts) to regain pluripotency [5,6]. This review will focus on stem cellderived self-organizing and self-renewing organoids, as defined by Lancaster and Knoblich [4]. Moreover, we will briefly mention other studies on 3D cell structures that do not feature stem cell-based self-renewal, and also do not demonstrate the recent criteria defining the term organoid [4].

Organoid cultures can typically be maintained for very long times (months, or even longer than a year), as shown for organoids derived from e.g. intestine [2], stomach [7], liver [8], and pancreas [9], as well as for iPSC-derived [10] organoids and ESC-derived [11] organoids. Organoid cultures can remain committed to their tissue of origin and capable of recapitulating the pathology of disease when cultured with tissues derived from clinical patients $[12,13]$. Moreover, organoids can be easily cryopreserved [14] and cultures can be restored from cryopreserved stocks, retaining functionality similar to that of the tissue of origin. They are amenable to genetic manipulation [15], live imaging, gene expression analysis, sequencing and epigenetic analysis, and other standard biological analyses. Organoids contain multiple cell types, with tissue topology and cell-cell interaction resembling many key features of the in vivo organ or tissue [16] whereas cell lines are usually derived from tumors or have become cancerous in vitro. Cancer-derived cell lines typically possess chromosomal aberrations and mutations [17] affecting growth, metabolism and physiology and are known to evolve during continuous passage in vitro creating problems with reproducibility [18]. Organoids also have an advantage over tissue explants or primary cell cultures, which undergo senescence, cell death and necrosis over relatively short time spans, leading to poor reproducibility and accuracy of biological experiments. These qualities have led to an exponentially increasing interest in this field during the last decade [3, 4, 19], and organoid technology was announced as one of the biggest scientific advancements of 2013 by The Scientist [20] and "Method of the Year 2017" in the Nature Methods editorial [21].

As organoids can be derived from cells or tissue from individual humans or animals, they can be used for testing patient-specific drug response [22] or patientspecific-autologous-grafting of genetically "repaired" tissues [23, 24]. For farm animals, animal-specific organoids could potentially be used for in vitro phenotyping, testing in vitro characteristics of organoids that may be a proxy for traits of interest $[25,26]$.

In human biomedical research, organoids are finding broad applications as in vitro research models, for instance for studying toxicology, developmental processes, congenital diseases, infectious diseases [27, 28], cancer $[29,30]$ and in regenerative medicine [31].

In contrast, there have been relatively few studies on organoids in veterinary and animal production research, despite the potential application and impact in research on animal physiology, animal nutrition, host-microbe interaction (HMI), and for in vitro phenotyping of breeding animals. In this paper, we focus on organoid research in livestock and companion animals, reviewing the used methodologies, applications, and future prospective for organoid research in livestock and companion animals (Figure 1).

\section{Organoid derivation and culture methods}

Organoids can be generated from ASCs, ESCs, or iPSCs (Figure 2). ESCs are the stem cells from the inner cell mass of pre-implantation embryos. ASCs in principle are obtained from "mature" or adult tissue, but this is not necessarily tissue from adult animals but may be from juveniles or even from advanced embryos [3, 4]. ASCderived organoids are intrinsically programmed with their location-specific functions [32], making them more "adult-like" than organoids derived from iPSC or ESC, although the latter retain tissue-associated mesenchymal cells [33].

Under appropriate conditions, stem cells can divide to give rise to one daughter cell that maintains "stemness", while the other daughter cell can differentiate to a dedicated tissue-specific cell type. In tissues in vivo, the direct microenvironment, or "niche" of the stem cells and the differentiating daughter cells provide various signals that direct these processes and steer the direction of differentiation and thus determine what types of cells and tissue will develop. These signals include cell-to-cell contacts 


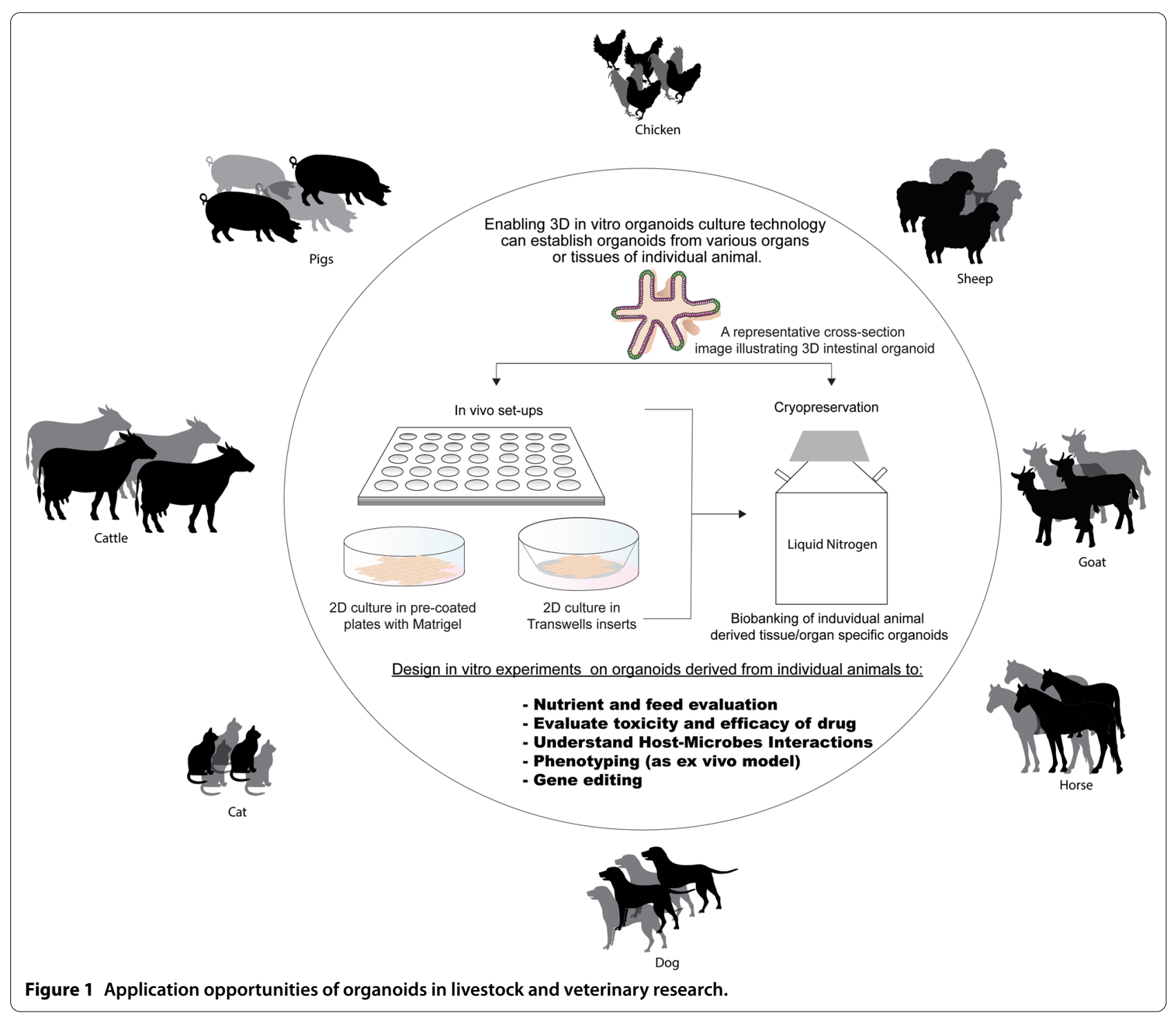

[34], contacts of cells to compounds of the ECM, autocrine growth factors and hormones from neighboring cells, from cells elsewhere in the tissue, or from peripheral organs [4]. The 3D architecture itself is instrumental in directing the spatial organization of cell lineages, as it creates gradients of growth factors determining the specific cellular differentiation steps [35].
The use of 3D culture matrices for organoids exploit the mechanisms that steer development of the cells in vivo. Therefore, the knowledge gained from stem cell biology and the insights obtained through $3 \mathrm{D}$ in vitro culturing methodology have been crucial in developing methods for generating organoid models for a multitude of organs [36]. 
Mimic adult niche

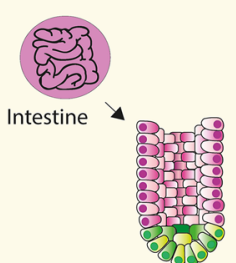

Intestinal crypt

$\downarrow$

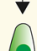

Adult stem cell (ASC)
Mimic developmental steps

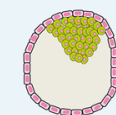

Developing embryo

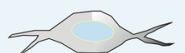

Adult differentiated cells, e.g. skin
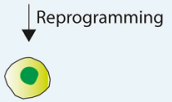

Embryonic stem cell

Induced pluripotent stem cell (iPSC)

Stem cell sources

(ESC)

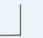

Pluripotent stem cell (PSC)
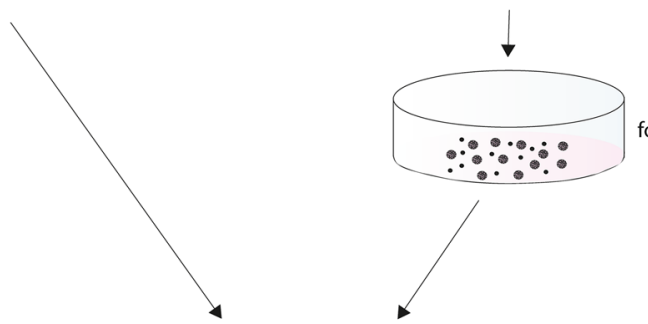

PSCs proliferate and form aggregates of cells
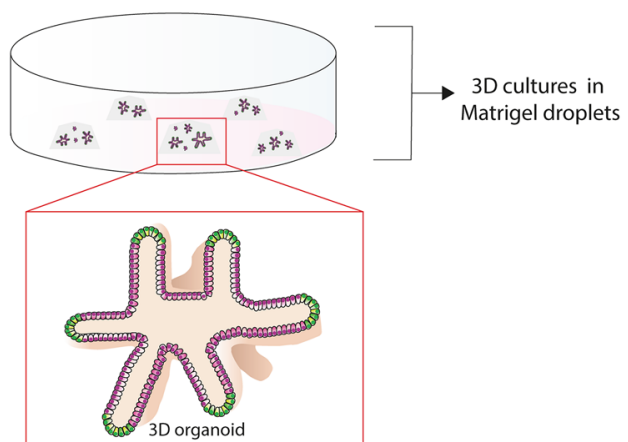

D organoids dissociated into single cells

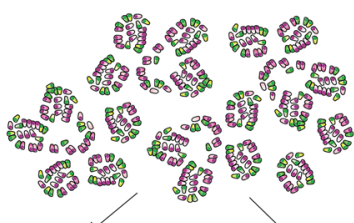

2D culture in pre-coated plates with Matrigel

2D culture in Transwells inserts

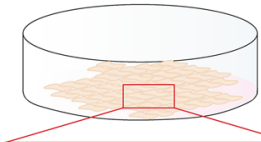

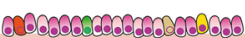

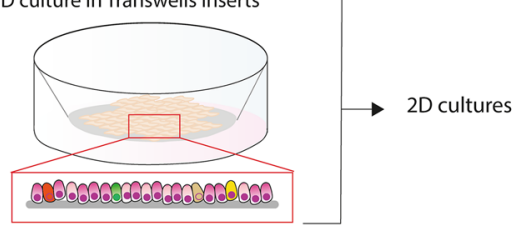

Figure 2 Current organoid culture techniques. Organoids can be derived from tissue samples containing adult stem cells (ASCs). Here, intestinal crypts are shown as example, but methods for other tissues (see main text) are similar. Organoids can also be derived from embryonic stem cells (ESCS), or induced pluripotent stem cells (iPSCs). Under appropriate conditions, using various growth factors and an extracellular matrix, such as matrigel (MG), the stem cells can proliferate while their daughter cells can differentiate to multiple cell types that self-organize into functional three dimensional (3D) structures. Different tissues require different (combinations of) growth factors. The 3D organoids can be dissociated, and plated onto membrane supports coated with MG or collagen, to form 2D monolayer organoid models. This is particularly useful of intestinal organoids as it allows access to the apical side, for instance to study interaction with microbes, or transport of nutrients. 
Table 1 Studies on tissue explants and re-aggregated dissociated cells in livestock and companion species

\begin{tabular}{lll}
\hline Species & Tissue & References \\
\hline Pigs & Intestine \& stomach & {$[145]$} \\
& Bile duct & {$[146]$} \\
& Liver & {$[147-151]$} \\
& Urinary bladder & {$[152]$} \\
& Testis & {$[44,45]$} \\
Chicken & Nervous and lymphoid tissue & {$[47]$} \\
& Skeletal muscles & {$[46]$} \\
Cattle & Arteries & {$[153-157]$} \\
& Articular cartilage & {$[158,159]$} \\
& Intestine & {$[160]$} \\
& Mammary gland & {$[48-52]$} \\
& Parathyroid gland & {$[161-166]$} \\
Dog & Intestine & {$[167]$} \\
\hline
\end{tabular}

Matrigel $^{\circledR}$ (MG), a de-cellularized ECM secreted by Engelbreth-Holm-Swarm mouse sarcoma cells [37], is typically used as matrix for 3D culture. Alternative ECMs include the synthetic hydrogel matrices [38]. Matrigel ${ }^{\circledR}$ provides specific signals conferred from the binding of cells to ECM components like ECM-proteins e.g. laminin, collagen IV, entactin/nidogen, heparan sulfate proteoglycans. Furthermore, it provides ECM-associated-growth factors like IGFs, FGFs, TGF-beta's, and HGF [39]. Moreover, the ECM density, stiffness, viscoelasticity, as well as topology and fibrosity are key ECM parameters that govern stem cell expansion and organoid formation [40].

In the case of epithelial organoids, the 3D structure can be a disadvantage for practical reasons. For instance, 3D intestinal organoids feature a miniature internal "lumen", very much like a true intestine, making it difficult to access the apical (luminal) side for studying interaction with microbes or trans-epithelial nutrient transport. For that reason, methods have been developed to generate two-dimensional (2D) polarized epithelial monolayers by seeding dissociated cells of 3D organoids onto MG or collagen-coated Transwell membranes [41-43], as described in more detail in Sect. 4.

\section{Research in major livestock and companion animals}

\subsection{Tissue-explants and re-aggregated dissociated cells}

In this section, we only briefly touch on studies on "organoid-like" 3D cultures that have used tissue explants and/or re-aggregated dissociated tissue cells, (Table 1). Many of these studies are focused on tissue engineering for repair or replacement, or for extracorporeal artificial organ devices, rather than on developing in vitro research models. However, the 3D cultures in some of the
Table 2 Summary of livestock and companion species organoid

\begin{tabular}{lll}
\hline Species & Tissue & References \\
\hline Pig & Esophagus submucosal gland & {$[58]$} \\
& Intestine & {$[43,53-56$,} \\
& & $59-64,71-74$, \\
& & $76-81]$ \\
Chicken & Rectum & {$[57]$} \\
Cattle & Intestine & {$[55,82-87]$} \\
Sheep & Intestine & {$[55,56,88,89]$} \\
& Pancreatic duct & {$[55]$} \\
Dog & Skin (Keratinocyte) & {$[90]$} \\
& Prostate gland & {$[93]$} \\
& Urinary bladder & {$[98]$} \\
& Kidney & {$[99]$} \\
& Intestine & {$[97]$} \\
& Liver & {$[55,91]$} \\
Cat & Intestine & {$[96]$} \\
& Liver & {$[55,100]$} \\
Horse & Intestine & {$[101,102]$} \\
\hline
\end{tabular}

earlier papers listed in Table 1 do seem to share certain features with self-renewing organoids, describing differentiation of organ-like structures from progenitor cells using ECM components and growth factors to induce 3D tissue development.

Two studies reported the production of porcine testicular "organoids" from dissociated testis [44, 45]. The developed testicular structures contained all relevant cell types in a 3D organization with physiological cell-cell interactions of germ cells with supporting cells [44]. In addition, the cultured testicular structures contained Sertoli cells and germ cells which assembled into seminiferous tubule-like structures delimited by a basement membrane along with Leydig cells and peritubular cells. In one of these studies, the cellular structures were maintained for 45 days [45]. However, long term self-renewal was not well-controlled, as the number of Sertoli cells increased and that of Leydig cells decreased over time. Yet, these organoids appear to provide an in vitro platform for studying germ cell function, testicular development, and drug toxicity in a cellular context representative of the testis in vivo.

In chicken, two early studies showed long term culture of 3D organ-like structures ("organoids") of chicken muscle [46] and nervous and lymphoid tissues [47], respectively. These studies used ECM (MG or collagen) and certain growth factors, but these models lacked continuous stem cell-driven proliferation.

In cattle, Ellis et al. reported long-term culture of bovine 3D mammary gland organoids that recapitulated 
glandular duct morphology and function [48]. Their culture methods included the use of ECM (collagen) and growth factors, such as IGF1, TGF $\beta$, and mammary gland extract. Similar methods were used by other authors [49-52].

\subsection{Stem cell-derived organoids in livestock and companion animals}

Stem cell-derived organoids that are capable of selfrenewal and self-organization in long-term culture (Figure 2), are listed in Table 2. In all these studies, organoids were derived from tissue ASCs. To our knowledge no published scientific studies are available on iPSC-derived organoids in farm or companion animals.

\subsubsection{Pig}

Intestinal organoids (enteroids) were the first organoids reported from pigs. Gonzalez et al. demonstrated development of enteroids in vitro from intestinal crypts from new-born piglets [53]. These enteroids showed budding (forming buds with a crypt-like structure) and contained the principal cell types of the intestinal epithelium including stem/progenitor cells, absorptive enterocytes, enteroendocrine cells, goblet cells, and Paneth-like cells. Later studies applied similar methods with small modifications that were necessary for, or contributed to, the development of enteroids from juvenile and adult pig intestinal tissue [54], or the ability to maintain the enteroids in culture for several months $[43,55,56]$. Organoids have also been derived successfully from the rectum [57], esophageal submucosal gland [58], and colon (often referred to as "colonoids") [59]. A recent study showed that differential gene- and pathway expression of independent organoid cultures from the same pig was stable over 12 weeks of culture [60]. Furthermore the batch-to-batch variation in organoid gene expression was low during long term culture, which may have aided by simultaneous passage to limit differences in their differentiation state. Moreover, in the same study, the authors also compared the transcriptomes profiles of jejunal organoids, the corresponding jejunum mucosa tissue from which the organoids were derived, and IPEC-J2 cells (a porcine cell line derived from the jejunum, often used as model for small intestinal epithelium). Below in Sect. 4.4, the same study is mentioned as "validation" in the lights that organoids are compared with tissue and IPEC-J2 cells.

Pig intestinal organoids have been applied to study nutrition, nutrient uptake, feed efficiency, and interaction with pathogenic microbes (viruses, bacteria). Koltes and Gabler have applied porcine intestinal organoids to study LPS-induced intestinal inflammation in pigs [61]. Likewise, Derricott et al. also produced and characterized murine, bovine, and porcine enteroids as potential research models for the study of speciesspecific intestinal infections with a variety of pathogens [56]. They demonstrated in vitro infection of bovine and porcine enteroids by the eukaryotic parasite Toxoplasma gondii and the bacterial pathogen Salmonella typhimurium. Resende et al. showed that Lawsonia intracellularis is capable of infecting and replicating intracellularly in 2D pig enteroids, which resulted in epithelial changes as observed in the Lawsonia-infected enteroids, specifically regarding the intestinal cell constitution and gene expression [62]. Further, a pig enteroid model was used to study porcine epidemic diarrhea virus (PEDV) infection $[63,64]$. The identity of the specific cell types targeted by PEDV in vivo has remained elusive. Most in vitro studies on PEDV infection have been performed in cell lines of other than pig origin, such as Vero cells from African green monkey kidney and HEK293 cells from human embryonic kidney [65-67]. Vero cells are incapable of producing type I interferons when infected by viruses [68]. PEDV clinical isolates generally do not replicate very well in IPEC-J2 cells either [69, 70]. In contrast, PEDV was shown to infect multiple types of epithelial cells of a porcine enteroid model, including enterocytes, stem cells, and goblet cells $[63,64]$. These studies also provided insights into the porcine interferon defense mechanisms. Furthermore, pig enteroid model has been employed to study Porcine deltacoronavirus (PDCoV) tropism to different intestinal segments [71] and the molecular mechanisms of PDCoV infection [72]. Recently, Li et al. reported to have developed a porcine apical-out intestinal organoid culture system and verified its infectivity, type I and type III interferon (IFN) antiviral responses, and inflammatory responses following infection by a swine enteric virus i.e. by transmissible gastroenteritis virus [73]. Overall, the above cited studies on the interaction of pathogens with intestinal epithelia clearly shows the suitability of enteroids and colonoids as in vitro intestinal models to study host-pathogen interaction in pigs.

At the interface of nutritional and immune research, Ellen et al. used porcine enteroids and colonoids to study host-pathogen interaction in relation to feed efficiency [59]. Ferrandis et al. used porcine and murine enteroids to study the role of cytokines (like interleukins (IL)- $1 \beta$ and IL-4) in the regulation of mucin production (i.e. expression of the MUC2 gene) by the epithelium, as dietary fiber and fiber-degrading enzymes in pig feed are known to affect expression of cytokines in the gut [74]. They found different effects of interleukins in porcine and murine enteroids, which shows the importance of using species-specific in vitro models for the target animal species. Additionally, Olayanju et al. argued that the use of porcine intestinal organoids have great potential 
in human biomedical research, for drug screening and biomarker discovery, as, pigs are closer to humans in anatomy and physiology than rodents [75]. In biomedical research on epithelial injury or diseases, porcine organoids may offer possibilities, particularly in situations where collection of tissue samples in humans from the pathogenic site for producing organoids may be too invasive or might induce pathology. Towards this, Von Furstenberg et al. developed an organoid model for porcine esophageal submucosal glands (ESMGs) and showed that the organoid model could be used to study differentiation into squamous versus columnar epithelium, and the mechanisms of ESMG proliferation and regeneration of injured epithelium [58]. Likewise, several studies aimed at providing an animal (porcine) organoid model for (human) biomedical research on small intestinal stem cell physiology and epithelial regeneration in short bowel syndrome, ischemic injury, and other conditions related to intestine [53, 54, 76]. Further, Adegbola et al. derived organoids from the anorectal epithelium to study etiology of, and therapies for, perianal Crohn's fistulae [57]. Zhu et al. used porcine enteroids to study effects of (dietary) glutamate on pathways of importance for intestinal stem cell biology and intestinal epithelial proliferation [77]. Recently, Engevik et al. produced enteroids from genetically modified pigs to study microvillus inclusion disease, a rare genetic human disease of the intestine, characterized by chronic, watery, life-threatening diarrhea in infants [78].

In the area of pig nutrition, Wang et al. used pig enteroids as in vitro model, showing that vitamin A regulates the "stemness" of intestinal stem cells [79]. In other studies, porcine enteroids were used to demonstrate the impact of the food/feed-associated mycotoxin, deoxynivalenol [80] or the dietary amino acid l-Glutamate on intestinal stem cell activity, in particular by effects on molecular pathways that are essential for intestinal homeostasis and functionality $[77,81]$.

\subsubsection{Chicken}

Chicken intestinal organoids (small intestine, cecum) can be readily derived from sampled intestinal tissue following methods similar to those used for enteroids of pig and other species. Tissues were obtained from either prehatch chicklets [82-85], day-old male broiler chicks [86], young (2-3 week post-hatch) chicks [85, 87], or from adult chicken carcasses $[55,87]$.

Reverse transcriptase-polymerase chain reaction (RTPCR), immunoblot analysis, and immunofluorescence microscopy indicated that the chicken intestinal organoids expressed markers for crypt stem cells, and for proliferating, differentiating, and mature enterocytes [82,
85], as well as goblet cells, enterochromaffin-like-cells', and "Paneth-like" cells [86].

These studies give a clear outlook on applications of organoids, e.g. research on avian intestine physiology, drugs and feed absorption, interaction with microorganisms, and gut immunity [82, 85]. Pierzchalska et al. applied organoid cultures to study interactions of the intestinal epithelium with the probiotic Lactobacillus acidophilus, as well as ligands for toll-like receptors (TLR) 2 and TLR 4 [83, 84]. They described how organoids in culture can migrate and fuse with each other thereby forming bigger size organoids, and how this is influenced by the TLR4 ligand LPS. These results show the potential of chicken organoids to study early gut development and maturation as well as the interaction of the intestine with probiotic bacteria and with pathogenic and commensal microbiota, which is important for gut health and homeostasis, feed efficiency, and productivity.

\subsubsection{Cattle}

In several recent studies, bovine enteroids and colonoids have been generated (Table 2), using similar methods as described for other species. Like in other species, the bovine enteroids and colonoids could be maintained in culture for a long time $[55,88]$. Bovine enteroids have been characterized by microscopy and histology, 5-Ethynyl-2'-deoxyuridine (EdU) staining for proliferative activity [55], and transcriptome analysis [89]. It was shown that enteroids can be cryopreserved and thawed to start continued culture for at least several passages [56, 89]. Transcriptome analysis at various time points (passages) confirmed long-term stability of the organoid cultures [89]. As mentioned for the pig, also cattle enteroids were used to study the interaction with pathogens Toxoplasma gondii and Salmonella typhimurium [56].

\subsubsection{Sheep}

Powell et al. showed that sheep enteroids can be readily derived from terminal ileum tissue, using similar methods as for example used in pigs [55]. In fact, they showed that these methods can be applied with minor modifications to a range of farm and companion animals including cat, dog, cow, horse, pig, sheep and chicken. The sheep enteroids were maintained in culture for a very long time, i.e. 239 days or 66 passages. Histology and transcriptome analysis confirmed that the sheep enteroids contained the principle cell types of the intestine epithelium which include absorptive enterocytes and stem/progenitor cells.

Liu et al. have established sheep pancreatic duct organoids to investigate the role and mechanism of copper in the sheep pancreas [90]. They showed that moderate concentrations of copper promote sheep pancreatic duct organoids and detailed the molecular mechanism 
through which copper induces the cell proliferation in the organoids.

\subsubsection{Dog}

In several recent studies, organoids have been generated from tissues from various organs of the dog (Table 2). Powell et al. derived ileum enteroids that were maintained in culture for as long as 229 days or 64 passages [55]. Chandra and et al. obtained organoids from several duodenum, jejunum, ileum, and colon, which they maintained in culture for more than 20 passages [91]. Both groups demonstrated that the intestinal organoids could be cryopreserved, thawed and expanded, providing a banked resource for continued experimentation. Similar to enteroids in other species, such as the pig, intestinal organoids from dogs consisted of different cell populations of intestinal epithelium including stem/progenitor cells, absorptive enterocytes (having microvilli expressing brush-border enzymes), tuft cells (expressing SOX9 and DCLK1 genes), tight junctions and Paneth-like cells [91]. It is noteworthy that while Paneth cells are reported to be absent in dogs [92], however, Chandra and et al. demonstrated functionally equivalent cells (Paneth-like cells) in the dog intestinal epithelium and enteroids [91]. The same authors applied a number of functional assays that can demonstrate and quantify organoid epithelial functions, such as optical metabolic imaging, the cystic fibrosis transmembrane conductance regulator function assay, and an assay for the uptake of exosome-like vesicles (from the parasitic nematode Ascaris suis). Such assays may be used to "phenotype" performance and drug response of animal-specific dog enteroids, which might be relevant for both human and veterinary gastrointestinal research and "personalized" medicine.

Dog keratinocyte organoids were produced to address skin disorders and alopecia in dogs [93]. These organoids are generated from either micro-dissected hair follicles or interfollicular epidermis. They could be maintained in culture for several months, remaining phenotypically stable as characterized by gene expression analyses, microscopy, histology and protein expression analyses.

Dogs are often used as a model in human biomedicine research, as the dog for some diseases bridges the gap between (often used) rodent models and humans $[94,95]$. Using both wild type dogs and dogs deficient in COMMD1, which is essential for liver copper homeostasis, Nantasanti et al. developed a dog liver organoid culture system to validate stem cell and gene therapy strategies to cure copper storage disease in human [96]. Liver organoids were derived from fresh explanted or dimethyl sulfoxide (DMSO)-frozen liver, or from biopsy samples (wedge, or "Tru-Cut" or fine-needle aspiration biopsies) [96]. Like enteroids of dog and other species, the dog liver organoid cultures were maintained for as long as 8 months (28 passages) and could be resumed after cryopreservation of organoids. Furthermore, karyotype analysis of organoids showed that most cells $(>85 \%)$ retained the normal chromosome number, even after 8 months of culture [96], reflecting long-term genetic stability of the organoids. Further, budding tubule-like kidney organoids could be grown on MG from dissociated adult canine kidney cells [97], showing high self-renewal capacity in long-term culture ( $>13$ months). In this study, the authors hypothesized that the remarkable selfrenewal capacity and the differentiation towards tubular cells is due to induced STAT3 expression at high cell density in these cells.

In addition to organoids from healthy tissues, prostate cancer [98] and bladder cancer organoids [99] have been generated from cancerous cells in urine from dogs with prostate or bladder cancer, respectively. Both organoid models resembled histopathological characteristics and gene expression profiles of the original tissues, and could be useful tools to provide insights into cancer therapy in dogs and as a translational model in prostate and bladder cancers in human.

\subsubsection{Cat}

In cats, organoids have been generated successfully from intestine and liver (Table 2) using current organoid techniques (as described in Figure 2). Cat organoids have been used in biomedical research and/or in veterinary research for the species itself. Ileum tissue obtained from euthanized cats was used to generate enteroids that were maintained for 67 days or 18 passages in culture and could be cryopreserved [55]. Similar to the enteroids from other species, enteroids from cats formed budding structures with distinct regions of cell proliferation (shown by EdU staining) in areas exhibiting cryptlike budding and folding. The cat enteroids expressed crypt stem cell marker LGR5. But unlike enteroids in the other species, the mesenchymal marker vimentin was expressed quite strongly, which disappeared around passage 7-9, followed by cessation of expansion around passage 10 with further growth arrest around passage 13-18. This suggested that mesenchymal-like cell types are essential for cat enteroid growth. Recently, Tekes et al. reported to have generated colon-derived organoids and studied host-pathogen interactions and immune response against feline enteric coronavirus [100].

Cat liver organoids were generated from post-mortem liver samples which were maintained for 25 passages in culture condition [101]. Further, karyotyping analysis has shown $80-85 \%$ of the cell population in the liver organoid retaining the normal chromosome number (i.e. 38), when maintained up to 23 passages in culture, reflecting 
long-term genetic stability of the organoids. The liver organoids could be cryopreserved and formed organoids again upon thawing. Feline liver organoids expressed markers of adult stem cells (LGR5, PROM1, and BMI1); hepatic progenitor cells (KRT7, KRT19, and HNF1b); early hepatocytes (HNF4a and TBX3, ALB), and mature hepatocyte (PROX1, PC, HMGCL, TTR, FAH, and CYP3A132). Recently, in a study by the same research group using cat liver organoids, two potential drugs useful in the treatment of hepatic lipidosis in cats were recognized [102].

\subsubsection{Horse}

Enteroids have also been derived in the horse (Table 2), as an additional in vitro model for studying gastrointestinal developmental biology, interactions with nutrients or with (pathogenic) microbes. Enteroids were generated using intestinal samples from euthanized horses [ 55 , 103]. Immunofluorescent antibody histological staining and PCR indicated the presence of stem cells, enteroendocrine cells, absorptive enterocytes, goblet cells, and Paneth cells [103]. A long term maintenance (168 days, 46 passages) of horse enteroids has been reported [55], and enteroids could be cryopreserved, thawed, and expanded $[55,103]$.

\section{Potential improvements of organoid culture systems in livestock and veterinary research}

Organoids offer a great potential for livestock and veterinary research. There seems to be little restriction regarding the types of tissue/organ and species from which organoids could potentially be derived. This also applies to other farmed animal species not covered in this review, such as rabbit [104] and fish species, e.g. rainbow trout [105]. However, to increase the scope of (large scale) application of organoids several challenges need to be addressed.

\subsection{High throughput, low cost, reproducible organoid platforms}

Large scale applications of organoids would require reproducible, accurate, low-cost and high-throughput organoid platforms. Reproducibility may be improved by using well standardized protocols and more defined medium ingredients. Purified lyophilized (commercially available) niche factors appear to provide better defined and more constant quality than "conditioned medium", i.e. medium from cultures of recombinant cells expressing the required niche factors Noggin, R-spondin, and WNT3A. The ECM, MG, with its complex, poorly defined and variable composition may also contribute to variation in the physical and biochemical culture conditions $[106,107]$. Furthermore, the niche factors and MG contribute substantially to the high costs of organoid culture. For the culture of mouse intestinal organoids it was shown that epidermal growth factor can be replaced by lysophosphatidic acid [112]. Similarly, for the culture of chicken intestinal organoids, the expensive agonists R-spondin 1 and Noggin may be replaced by prostaglandin E2 [92]. As an alternative for MG, more defined and less costly biomaterials have been studied, like natural, synthetic and protein-engineered hydrogels [107-109].

The costs of organoid culture may also be reduced by using the "hanging drop culture", which physically favors cell-to-cell interactions due to the lack of rigid support or solidified ECM scaffold [82]. This method features a lower concentration of MG (only 5\%), resulting in an overall $70 \%$ lower expenditure of MG in comparison to the standard protocol [82]. In addition, this hanging drop culture method takes less time as it does not involve MG solidification. A recent review paper [38], describes how microfabrication methods and devices, such as lithography, microcontact printing, and microfluidic delivery systems, can help overcome current limitations of organoid culture regarding complexity, throughput, and reproducibility. In a study on bovine colonoids, Töpfer et al. introduced methodological advances such as extrusion bioprinting of colonoid fragments into multi-well plates as an alternative seeding and culture methodology, as well as in-plate cryopreservation as convenient alternative to conventional in-vial cryopreservation to enable a "plug and play" format for cell-based bio-efficacy and biosafety testing [88]. This and other cost and time effective findings may contribute to producing high throughput organoid platforms from various tissue/organs from livestock and companion animals.

\subsection{D organoid platforms}

To enable access to the apical membrane of epithelial organoids, which is necessary to study e.g. interaction with microbes or transport of nutrients, 2D organoid models have been developed [41-43, 110-112]. It is necessary for farm animals that such 2D models are developed and validated. Recently, for pig intestinal organoids such 2D cultures on Transwell membranes have been established and used [43]. These 2D organoids are amenable for high-throughput systems e.g. measuring transcriptome response to variables of interests, including interactions with feed ingredients, drugs or pathogenic microorganisms [62, 72]. Furthermore, 2D intestinal organoid models allow electrophysiological studies using Ussing chambers as well as measurement of trans-epithelial permeability and electrical resistance as read-outs for intestinal (organoid) function which are relevant for studying "transport capacity" of the intestine. Such abilities make the 2D intestinal organoid model a powerful 
and sophisticated experimental model of mammalian biology for studying complex interactions occurring in the intestinal lumen. However, 2D models can also have disadvantages compared to 3D models. The 2D monolayers can contain all cell lineages found in ASC-derived organoids [43], but in other studies (reviewed in [113]) it has also been reported that some cell types present in 3D organoids may not be represented in 2D cultures. Moreover, the propagation from $2 \mathrm{D}$ to $2 \mathrm{D}$ can only be accomplished for a limited number of iterations [114].

\subsection{Collection of tissue samples; biopsies}

Organoids in livestock and companion animals have only been produced from "parent" tissues (containing ASCs) collected from abattoir or euthanized animals. If animals need to be sacrificed specifically for this purpose, this would not comply with the 3R concept-Replacement, Reduction and Refinement. Also, the sacrifice of animals would not be desired by livestock breeders if the animals belong to their valued nucleus breeding population nor by animal owners in case of companion animals. Enabling the collection of tissue samples by biopsy, a common practice to collect tissue from human, can be a solution to collect "parent" tissue to culture organoids from livestock and companion animals, provided this can be achieved with minimal discomfort for the animals. A limited number of research articles reported collection of biopsies for the production of intestinal organoids in pigs $[54,115]$. We have recently carried out a pilot study with the aim of using biopsy materials to culture intestinal organoids in pigs (unpublished). With the aid of colonoscopy, we collected sufficient biopsied tissue samples and successfully produced colonoids from these samples. Similarly, biopsy techniques (including needle biopsy [96]) may be used for obtaining tissue samples to produce organoids from other organs including gastrointestinal-, respiratory-, urinary-, and reproductive- tracts, as well as liver, mammary gland, fat and muscle, collected from livestock and companion animals. However, if this would be applied, utmost care must be given to minimizing discomfort or pain. When tissues from several organs are to be taken it may most likely require the sacrifice of an animal. The possibility of re-use of organoids (especially generated in a serum-free organoid culture system) stored in a biorepository would be in line with the 3Rs. Additionally, interesting non-invasive approaches seem to be possible in specific cases. For example from urine, human kidney tubuloids [116] and dog prostate cancer, organoids [98] have been cultured and expanded. It would be interesting to explore if similar approaches would be feasible for producing udder organoids from (stem) cells in milk for dairy cattle.

\subsection{Validation}

It is important to validate organoids as a model for the organ or tissue of origin, or even as proxy for in vivo performance characteristics and animal (genetic) differences thereof. This would involve comparing characteristics and performance of tissue from animals, or even of intact animals, with characteristics and performance of organoids derived from these tissues. There have been only a few studies in that regard in livestock and companion animal species. In the pig, Van der Hee et al., have compared the transcriptomes profiles of jejunal organoids, the corresponding jejunum mucosa tissue from which the organoids were derived, and IPEC-J2 cells [60]. They found that the set of genes expressed in the organoids closely resembled that of the tissue of origin, including small intestine-specific genes, most of which were not expressed in the IPEC-J2 cells. Regarding nutrient uptake studies, mouse and human organoid models have been validated in a qualitative sense as valuable tool [117]. In a quantitative sense, studies would be needed to compare both expression of transporter proteins and actual nutrient transport kinetics with uptake kinetics of intestinal tissue measured in Ussing chambers [118] or with uptake kinetics measured in live (farm) animals [119]. Preferably, organoids derived from animals that have a clear contrast in a trait such as disease resistance or feed efficiency could be compared. For instance we are currently looking at genome wide gene expression of intestinal organoids derived from pigs with different feed efficiency $[59,120]$.

\subsection{Development of more complex systems}

The in vivo intestine contains, in addition to the epithelium, a complex immune and neural system. In the in vitro organoid system, this complex immune and neural system is lacking, which reduces its ability to study interactions between these (sub)systems. Co-culturing of organoids with immune or neural cells and providing tissue specific biochemical cues resembling the in vivo condition could in part enable the study of such interactions. However, co-culture of various cell types in an organoid system has not been reported for livestock and companion animals yet. Techniques such as 3D bioprinting (e.g. $[38,88])$ for seeding culture devices may enable co-culturing of various cell types with defined spatial positioning to generate more complex organoid systems that may better mimic the in vivo host physiology.

\section{Potential uses of organoids in livestock and veterinary research}

\subsection{Fundamental biology and pathology}

The respiratory, gastrointestinal, urogenital, and mammary epithelia, along with the skin, are the most 
important sites of contact with the outside environment, with intimate contacts with the respective microbiomes of these organs, including potential pathogens. While interaction with microbes has mostly been studied in organoid models of intestinal epithelia of different species [55, 56, 59, 61-64, 71-73, 83, 84, 91, 100, 103], similar studies could be done in organoid models as have been done in human and rodents for the lung [121] and the mammary gland [122]. In the gut, the epithelium is constantly screening the contents of the intestinal lumen $[123,124]$. Intestinal immune signaling can be triggered by nutrients, the digestion products from feed, and the intestinal microbiome, including pathobionts. The signaling modulates the innate and the adaptive immune system while trying to maintain a balance between pro- and anti-inflammatory conditions to preserve gut health and homeostasis [73]. Some aspects of this sensing and signaling may be studied in intestinal organoids, for instance the production of, and response to immune signaling molecules such as cytokines and/or enteroendocrine hormones [74, 125, 126].

Research on primary epithelial samples form human fetal and pediatric samples has shown changes in DNA methylation associated with different expression programmes [127]. These changes are likely to be mediated by the exposure to environmental factors changing during early life. Epigenetic modifications have also been reported in colon cancer, for example hypermethylation of the promoters of tumour suppressor genes influencing tumour growth [128]. Research emerging from biomedical domain provide evidences that organoids offer possibility to study epigenetics in health and diseases [129-131]. In livestock or veterinary research, organoids (of relevant tissue) from livestock or companion animal species could be employed as a tool to study epigenetics, that may generate new knowledge towards various aspects of early life programming or imprinting in livestock species [132, 133] acquired via the nutritional or managemental practices adopted in animal husbandry.

\subsection{Nutritional research}

In the area of animal nutrition, intestinal organoids may be used to study the gastro-intestinal epithelial response to feed ingredients (as has been done with mouse organoids [112]). Performing such studies could aid nutritionist to determine "non-strict-nutritional" properties e.g. anti-oxidative and oxidative effects, immune responses and signaling, arising from digestion of proteins [134], carbohydrate [135] or other dietary components [136].

\subsection{Breeding}

A wholly different concept of implementing organoids is their use for phenotyping animals for the purpose of selective breeding. Here, the goal is not necessarily to advance our understanding of animal traits, or to understand specific mechanisms, but simply to characterize ("phenotype") organoids of as many as possible animals with known genotypes. This could be an important tool to further improve production performance in livestock. For instance, in finding quantitative trait loci (QTLs) and potentially causative genes for specific traits by searching for genome wide associations between specific phenotypes and genomic information [25, 26, 137]. Organoids may also contribute to genomic selection, in which the genetic merit of breeding stock is not directly obtained by phenotyping but is rather inferred from genomic information for which the relationship with the phenotype is established in a "training" population of phenotyped animals $[138,139]$. It can thus be envisaged that a repository of organoids is established from animals representing the training population. In vitro phenotyping of these organoids could then be used instead of, or in addition to, "normal" phenotyping of these animals, as this would provide phenotypic information on more defined underlying (cellular, molecular) aspects of the traits of interest. Livestock improvement currently has a focus on traits related to animal health and resilience, animal welfare, and feed efficiency [140, 141]. Animals may have genotypic differences regarding their interaction with microbes and this may manifest itself on a cellular or molecular phenotypic level. Organoids representing the relevant epithelia may be suited for measuring certain aspects of the interaction with microbes or the transport of nutrients $[59,120]$. Large-scale application of organoids in breeding programs would require a highthroughput and low-cost organoid platform allowing standardized, reproducible and accurate measurements of in vitro performance of epithelial functions. Further, if tissues for deriving organoids could be obtained from biopsies from live animals (discussed in Sect. 4), this would have the advantage that after in vitro phenotyping the high merit animals are still available as breeding stock.

\subsection{Routine testing}

Lastly, organoids may be used to constitute a routine testing platform. Here, the goal is not necessarily to understand mechanisms or develop medicines or diets, but rather to apply (validated) relationships. For instance, organoid platforms may be made available for testing of effectiveness and side effects of (veterinary) drugs. Largescale and high-throughput organoid platforms could also be made available for routine toxicologic testing [142], or for routine quality testing of diet or feed ingredients [80, 143]. Also, for human health, human (or animal) organoid platforms may be used for routine testing of 
products for human consumption [144]. Especially in such routine applications, organoids and other in vitro or ex vivo models can contribute to a reduction of animal studies, in line with the principles of the 3Rs.

\section{Conclusion}

Organoids can be important in vitro research tools, in fundamental, applied, or routine aspects of veterinary and animal production sciences and may complement and partly replace animal studies. This would require more research, especially regarding organoids of other organs, as the majority of studies have been on intestinal organoids. Organoids have distinctive advantages over other in vitro models, as they better recapitulate structure and function of tissues. Compared to intact organs they are strongly reduced models, which may be an advantage for studies on specific mechanisms, but also confers clear limitations to the model. Organoids thus provide a well-defined, accessible research model that may be used to obtain phenotypic information on defined underlying cellular and molecular aspects of important complex traits such as feed efficiency and disease resistance. Thus, organoids can be of great value in livestock and veterinary research.

\begin{abstract}
Abbreviations
2D: Two-dimensional; 3D: Three-dimensional; 3Rs: Replacement, reduction and refinement; ASCs: Adult stem cells; CRIPR-Cas9: Clustered regularly interspaced short palindromic repeats and CRISPR-associated protein 9; DMSO: Dimethyl sulfoxide; ECM: Extracellular matrix; EdU: Ethynyl-2'-deoxyuridine; ESCs: Embryonic stem cells; ESMG: Esophageal submucosal glands; HMI: Hostmicrobe interaction; IPEC: Intestinal porcine epithelial cell line; iPSCs: Induced Pluripotent stem cells; LPS: Lipopolysaccharide; PDCoV: Porcine delta corona virus; PEDV: Porcine epidemic diarrhea virus; PSCs: Pluripotent stem cells; QTLs: Quantitative trait loci; TLR: Toll-like receptors.
\end{abstract}

\section{Acknowledgements}

The authors would like to thank the team members of KB37 "Healthy and safe food systems" and the Breed4Food partners who participated in the preliminary discussions that helped in shaping the outline of this manuscript.

\section{Authors' contributions}

SKK and HW collected literature references, organized the manuscript outline, wrote the initial draft of the manuscript and editing. SKK prepared the figures. SKK, JMW, MFWtP, OM, MAMG, EDE, HW provided critical reviews of the content. SKK, JMW, MAMG, and HW provided intellectual oversight, suggestions, and multiple critiques. All authors read and approved the final manuscript.

\section{Funding}

This study was financially supported by the Dutch Ministry of Economic Affairs (TKI Agri \& Food project 16022) and the Breed4Food partners Cobb Europe, CRV, Hendrix Genetics and Topigs Norsvin. Furthermore, this study is a part of research and development initiative plan of Wageningen Research i.e. KB37 "Healthy and safe food systems" that has received financial support from Dutch Ministry of Agriculture, Nature and Food Quality (LNV).

\section{Availability of data and materials}

Not applicable

Ethics approval and consent to participate Not applicable.
Consent for publication

All the authors read and approved the manuscript.

\section{Competing interests}

The authors declare that they have no competing interests.

\section{Author details}

${ }^{1}$ Wageningen Livestock Research, Wageningen University \& Research, Wageningen, The Netherlands. ${ }^{2}$ Host-Microbe Interactomics, Wageningen University \& Research, Wageningen, The Netherlands. ${ }^{3}$ Animal Breeding and Genomics, Wageningen University \& Research, Wageningen, The Netherlands.

Received: 7 August 2020 Accepted: 13 January 2021

Published online: 10 March 2021

\section{References}

1. Eiraku M, Watanabe K, Matsuo-Takasaki M, Kawada M, Yonemura S, Matsumura M, Wataya T, Nishiyama A, Muguruma K, Sasai Y (2008) Self-organized formation of polarized cortical tissues from ESCs and its active manipulation by extrinsic signals. Cell Stem Cell 3:519-532. https ://doi.org/10.1016/j.stem.2008.09.002

2. Sato T, Vries RG, Snippert HJ, van de Wetering M, Barker N, Stange DE, van Es JH, Abo A, Kujala P, Peters PJ, Clevers H (2009) Single Lgr5 stem cells build crypt-villus structures in vitro without a mesenchymal niche. Nature 459:262-265

3. Fatehullah A, Tan SH, Barker N (2016) Organoids as an in vitro model of human development and disease. Nat Cell Biol 18:246-254

4. Lancaster MA, Knoblich JA (2014) Organogenesis in a dish: modeling development and disease using organoid technologies. Science 345:1247125. https://doi.org/10.1126/science.1247125

5. Takahashi K, Yamanaka S (2006) Induction of pluripotent stem cells from mouse embryonic and adult fibroblast cultures by defined factors. Cell 126:663-676. https://doi.org/10.1016/j.cell.2006.07.024

6. Takahashi K, Yamanaka S (2016) A decade of transcription factor-mediated reprogramming to pluripotency. Nat Rev Mol Cell Biol 17:183-193. https://doi.org/10.1038/nrm.2016.8

7. Barker N, Huch M, Kujala P, van de Wetering M, Snippert HJ, van Es $J$, Sato T, Stange DE, Begthel H, van den Born M, Danenberg E, van den Brink S, Korving J, Abo A, Peters PJ, Wright N, Poulsom R, Clevers $H$ (2010) Lgr5(+ve) stem cells drive self-renewal in the stomach and build long-lived gastric units in vitro. Cell Stem Cell 6:25-36. https://doi. org/10.1016/j.stem.2009.11.013

8. Huch M, Dorrell C, Boj SF, van Es JH, Li VS, van de Wetering M, Sato T, Hamer K, Sasaki N, Finegold MJ, Haft A, Vries RG, Grompe M, Clevers H (2013) In vitro expansion of single Lgr5 + liver stem cells induced by Wnt-driven regeneration. Nature 494:247-250. https://doi.org/10.1038/ nature 11826

9. Huch M, Bonfanti P, Boj SF, Sato T, Loomans CJM, van de Wetering M, Sojoodi M, Li VSW, Schuijers J, Gracanin A, Ringnalda F, Begthel H, Hamer K, Mulder J, van Es JH, de Koning E, Vries RGJ, Heimberg H, Clevers $\mathrm{H}$ (2013) Unlimited in vitro expansion of adult bi-potent pancreas progenitors through the Lgr5/R-spondin axis. EMBO J 32:2708-2721. https://doi.org/10.1038/emboj.2013.204

10. Akbari S, Sevinç GG, Ersoy N, Basak O, Kaplan K, Sevinç K, Ozel E, Sengun B, Enustun E, Ozcimen B, Bagriyanik A, Arslan N, Önder TT, Erdal E (2019) Robust, long-term culture of endoderm-derived hepatic organoids for disease modeling. Stem Cell Reports 13:627-641. https://doi. org/10.1016/j.stemcr.2019.08.007

11. Matsui TK, Matsubayashi M, Sakaguchi YM, Hayashi RK, Zheng C, Sugie K, Hasegawa M, Nakagawa T, Mori E (2018) Six-month cultured cerebral organoids from human ES cells contain matured neural cells. Neurosci Lett 670:75-82. https://doi.org/10.1016/j.neulet.2018.01.040

12. Bigorgne AE, Farin HF, Lemoine R, Mahlaoui N, Lambert N, Gil M, Schulz A, Philippet P, Schlesser P, Abrahamsen TG, Oymar K, Davies EG, Ellingsen CL, Leteurtre E, Moreau-Massart B, Berrebi D, Bole-Feysot C, Nischke P, Brousse N, Fischer A, Clevers H, de Saint Basile G (2014) TTC7A mutations disrupt intestinal epithelial apicobasal polarity. J Clin Invest 124:328-337. https://doi.org/10.1172/JC171471 
13. Wiegerinck $C L$, Janecke $A R$, Schneeberger $K$, Vogel GF, van HaaftenVisser DY, Escher JC, Adam R, Thoni CE, Pfaller K, Jordan AJ, Weis CA, Nijman IJ, Monroe GR, van Hasselt PM, Cutz E, Klumperman J, Clevers $\mathrm{H}$, Nieuwenhuis EE, Houwen $\mathrm{RH}$, van Haaften G, Hess MW, Huber LA, Stapelbroek JM, Muller T, Middendorp S (2014) Loss of syntaxin 3 causes variant microvillus inclusion disease. Gastroenterology 147:65-68.e10. https://doi.org/10.1053/j.gastro.2014.04.002

14. Lu Y-C, Fu D-J, An D, Chiu A, Schwartz R, Nikitin AY, Ma M (2017) Scalable production and cryostorage of organoids using core-shell decoupled hydrogel capsules. Adv Biosyst. https://doi.org/10.1002/adbi.201700165

15. Miyoshi H, Stappenbeck TS (2013) In vitro expansion and genetic modification of gastrointestinal stem cells in spheroid culture. Nat Protoc 8:2471-2482. https://doi.org/10.1038/nprot.2013.153

16. Gjorevski N, Ranga A, Lutolf MP (2014) Bioengineering approaches to guide stem cell-based organogenesis. Development 141:1794-1804. https://doi.org/10.1242/dev.101048

17. Leung E, Kim JE, Askarian-Amiri M, Finlay GJ, Baguley BC (2014) Evidence for the existence of triple-negative variants in the MCF-7 breast cancer cell population. Biomed Res Int 2014:836769. https://doi. org/10.1155/2014/836769

18. Ben-David U, Siranosian B, Ha G, Tang H, Oren Y, Hinohara K, Strathdee CA, Dempster J, Lyons NJ, Burns R, Nag A, Kugener G, Cimini B, Tsvetkov P, Maruvka YE, O'Rourke R, Garrity A, Tubelli AA, Bandopadhayay P, Tsherniak A, Vazquez F, Wong B, Birger C, Ghandi M, Thorner AR, Bittker JA, Meyerson M, Getz G, Beroukhim R, Golub TR (2018) Genetic and transcriptional evolution alters cancer cell line drug response. Nature 560:325-330. https://doi.org/10.1038/s41586-018-0409-3

19. Xu H, Jiao Y, Qin S, Zhao W, Chu Q, Wu K (2018) Organoid technology in disease modelling, drug development, personalized treatment and regeneration medicine. Exp Hematol Oncol 7:30. https://doi. org/10.1186/s40164-018-0122-9

20. Grens K (2013) 2013's Big Advances in Science. The Scientist, New York City

21. An update on organoid research (2018) Nat Cell Biol 20:633-633. https ://doi.org/10.1038/s41556-018-0119-y

22. Kondo J, Inoue M (2019) Application of cancer organoid model for drug screening and personalized therapy. Cells 8:470. https://doi. org/10.3390/cells8050470

23. Nie Y-Z, Zheng Y-W, Ogawa M, Miyagi E, Taniguchi H (2018) Human liver organoids generated with single donor-derived multiple cells rescue mice from acute liver failure. Stem Cell Res Ther 9:5. https://doi. org/10.1186/s13287-017-0749-1

24. van den Berg CW, Ritsma L, Avramut MC, Wiersma LE, van den Berg $B M$, Leuning DG, Lievers E, Koning M, Vanslambrouck JM, Koster AJ, Howden SE, Takasato M, Little MH, Rabelink TJ (2018) Renal subcapsular transplantation of PSC-derived kidney organoids induces neo-vasculogenesis and significant glomerular and tubular maturation in vivo. Stem Cell Reports 10:751-765. https://doi.org/10.1016/j.stemcr.2018.01.041

25. Giuffra E, Tuggle CK, and the FAANG Consortium (2019) Functional Annotation of Animal Genomes (FAANG): current achievements and roadmap. Annu Rev Anim Biosci 7:65-88. https://doi.org/10.1146/annur ev-animal-020518-114913

26. Clark EL, Archibald AL, Daetwyler HD, Groenen MAM, Harrison PW, Houston RD, Kühn C, Lien S, Macqueen DJ, Reecy JM, Robledo D, Watson M, Tuggle CK, Giuffra E (2020) From FAANG to fork: application of highly annotated genomes to improve farmed animal production. Genome Biol 21:285. https://doi.org/10.1186/s13059-020-02197-8

27. Finkbeiner SR, Zeng X-L, Utama B, Atmar RL, Shroyer NF, Estes MK (2012) Stem cell-derived human intestinal organoids as an infection model for rotaviruses. MBio 3:e00159. https://doi.org/10.1128/mBio.00159-12

28. Castellanos-Gonzalez A, Cabada MM, Nichols J, Gomez G, White AC Jr (2013) Human primary intestinal epithelial cells as an improved in vitro model for Cryptosporidium parvum infection. Infect Immun 81:19962001. https://doi.org/10.1128/iai.01131-12

29. Tuveson D, Clevers H (2019) Cancer modeling meets human organoid technology. Science 364:952-955. https://doi.org/10.1126/scien ce.aaw6985

30. Lancaster MA, Renner M, Martin C-A, Wenzel D, Bicknell LS, Hurles ME, Homfray T, Penninger JM, Jackson AP, Knoblich JA (2013) Cerebral organoids model human brain development and microcephaly. Nature 501:373-379. https://doi.org/10.1038/nature12517
31. Nakamura T, Sato T (2018) Advancing intestinal organoid technology toward regenerative medicine. Cell Mol Gastroenterol Hepatol 5:51-60. https://doi.org/10.1016/j.jcmgh.2017.10.006

32. Middendorp S, Schneeberger K, Wiegerinck CL, Mokry M, Akkerman RD, van Wijngaarden S, Clevers H, Nieuwenhuis EE (2014) Adult stem cells in the small intestine are intrinsically programmed with their locationspecific function. Stem Cells 32:1083-1091. https://doi.org/10.1002/ stem. 1655

33. Wells JM, Spence JR (2014) How to make an intestine. Development 141:752-760. https://doi.org/10.1242/dev.097386

34. Morrison SJ, Spradling AC (2008) Stem cells and niches: mechanisms that promote stem cell maintenance throughout life. Cell 132:598-611. https://doi.org/10.1016/j.cell.2008.01.038

35. Sato T, Clevers H (2013) Growing self-organizing mini-guts from a single intestinal stem cell: mechanism and applications. Science 340:11901194. https://doi.org/10.1126/science.1234852

36. McCauley HA, Wells JM (2017) Pluripotent stem cell-derived organoids: using principles of developmental biology to grow human tissues in a dish. Development 144:958-962. https://doi.org/10.1242/dev.140731

37. Kibbey MC (1994) Maintenance of the EHS sarcoma and Matrigel preparation. J Tissue Cult Meth 16:227-230. https://doi.org/10.1007/ BF01540656

38. Velasco V, Shariati SA, Esfandyarpour R (2020) Microtechnology-based methods for organoid models. Microsyst Nanoeng 6:76. https://doi. org/10.1038/s41378-020-00185-3

39. Taipale J, Keski-Oja J (1997) Growth factors in the extracellular matrix. Faseb J 11:51-59. https://doi.org/10.1096/fasebj.11.1.9034166

40. Gjorevski N, Sachs N, Manfrin A, Giger S, Bragina ME, Ordóñez-Morán P, Clevers H, Lutolf MP (2016) Designer matrices for intestinal stem cell and organoid culture. Nature 539:560-564. https://doi.org/10.1038/ nature20168

41. VanDussen KL, Marinshaw JM, Shaikh N, Miyoshi H, Moon C, Tarr PI, Ciorba MA, Stappenbeck TS (2015) Development of an enhanced human gastrointestinal epithelial culture system to facilitate patientbased assays. Gut 64:911-920. https://doi.org/10.1136/gutjnl-2013306651

42. Moon C, VanDussen KL, Miyoshi H, Stappenbeck TS (2014) Development of a primary mouse intestinal epithelial cell monolayer culture system to evaluate factors that modulate IgA transcytosis. Mucosal Immunol 7:818-828. https://doi.org/10.1038/mi.2013.98

43. van der Hee B, Loonen LMP, Taverne N, Taverne-Thiele JJ, Smidt H, Wells JM (2018) Optimized procedures for generating an enhanced, near physiological 2D culture system from porcine intestinal organoids. Stem Cell Res 28:165-171. https://doi.org/10.1016/j.scr.2018.02.013

44. Sakib S, Yu Y, Voigt A, Ungrin M, Dobrinski I (2019) Generation of porcine testicular organoids with testis specific architecture using microwell culture. J Vis Exp. https://doi.org/10.3791/60387

45. Vermeulen M, Del Vento F, Kanbar M, Pyr Dit Ruys S, Vertommen D, Poels J, Wyns C (2019) Generation of organized porcine testicular organoids in solubilized hydrogels from decellularized extracellular matrix. Int J Mol Sci 20:5476. https://doi.org/10.3390/ijms20215476

46. Chromiak JA, Shansky J, Perrone C, Vandenburgh HH (1998) Bioreactor perfusion system for the long-term maintenance of tissue-engineered skeletal muscle organoids. Vitro Cell Dev Biol Anim 34:694-703. https:// doi.org/10.1007/s11626-998-0065-2

47. Chalisova NI, Penniyainen VA, Kharitonova NV, Nozdrachev AD (2001) The dynamics of stimulating and inhibiting influence on organoid cultures of nervous and lymphoid tissues. Dokl Biol Sci 380:424-426

48. Ellis S, Purup S, Sejrsen K, Akers RM (2000) Growth and morphogenesis of epithelial cell organoids from peripheral and medial mammary parenchyma of prepubertal heifers. J Dairy Sci 83:952-961. https://doi. org/10.3168/jds.S0022-0302(00)74959-9

49. Weber MS, Purup S, Vestergaard M, Akers RM, Sejrsen K (2000) Nutritional and somatotropin regulation of the mitogenic response of mammary cells to mammary tissue extracts. Domest Anim Endocrinol 18:159-164. https://doi.org/10.1016/s0739-7240(99)00071-5

50. Holland MS, Stasko JA, Holland RE (2007) Influence of extracellular matrix on bovine mammary gland progenitor cell growth and differentiation. Am J Vet Res 68:476-482. https://doi.org/10.2460/ajvr.68.5.476

51. Yamaji D, Kamikawa A, Soliman MM, Ito T, Ahmed MM, Makondo K, Watanabe A, Saito M, Kimura K (2007) Leptin inhibits hepatocyte 
growth factor-induced ductal morphogenesis of bovine mammary epithelial cells. Jpn J Vet Res 54:183-189

52. Martignani E, Accornero P, Miretti S, Baratta M (2018) Bovine mammary organoids: a model to study epithelial mammary cells. Methods Mol Biol 1817:137-144. https://doi.org/10.1007/978-1-4939-8600-2_14

53. Gonzalez LM, Williamson I, Piedrahita JA, Blikslager AT, Magness ST (2013) Cell lineage identification and stem cell culture in a porcine model for the study of intestinal epithelial regeneration. PLOS ONE 8:e66465

54. Khalil HA, Lei NY, Brinkley G, Scott A, Wang JF, Kar UK, Jabaji ZB, Lewis M, Martin MG, Dunn JCY, Stelzner MG (2016) A novel culture system for adult porcine intestinal crypts. Cell Tissue Res 365:123-134. https://doi. org/10.1007/s00441-016-2367-0

55. Powell RH, Behnke MS (2017) WRN conditioned media is sufficient for in vitro propagation of intestinal organoids from large farm and small companion animals. Biol Open 6:698-705. https://doi.org/10.1242/ bio.021717

56. Derricott H, Luu L, Fong WY, Hartley CS, Johnston LJ, Armstrong SD, Randle N, Duckworth CA, Campbell BJ, Wastling JM, Coombes JL (2018) Developing a 3D intestinal epithelium model for livestock species. Cell Tissue Res. https://doi.org/10.1007/s00441-018-2924-9

57. Adegbola S, Moore J, Sahnan K, Tozer P, Phillips R, Warusavitarne J, Faiz O, Hart A (2017) Establishing a porcine model to translate anorectal stem cell organoid models to elucidate the aetiology of perianal Crohn's fistulae. J Crohns Colitis 11:S81-S82

58. von Furstenberg RJ, Li J, Stolarchuk C, Feder R, Campbell A, Kruger L, Gonzalez LM, Blikslager AT, Cardona DM, McCall SJ, Henning SJ, Garman KS (2017) Porcine esophageal submucosal gland culture model shows capacity for proliferation and differentiation. Cell Mol Gastroenterol Hepatol 4:385-404. https://doi.org/10.1016/j.jcmgh.2017.07.005

59. Ellen ED, Taverne N, Taverne-Thiele JJ, Madsen O, Woelders H, Bergsma R, Knol EF, Kar SK, Haas Yd, Groenen M, Wells JM (2018) Intestinal stemcell organoids as experimental models to investigate feed efficiency. Paper presented at the 69th Annual Meeting of the European Federation of Animal Science, Dubrovnik, Croatia, 28-08-2018

60. van der Hee B, Madsen O, Vervoort J, Smidt H, Wells JM (2020) Congruence of transcription programs in adult stem cell-derived jejunum organoids and original tissue during long-term culture. Front Cell Dev Biol 8:375. https://doi.org/10.3389/fcell.2020.00375

61. Koltes DA, Gabler NK (2016) Characterization of porcine intestinal enteroid cultures under a lipopolysaccharide challenge. J Anim Sci 94:335-339. https://doi.org/10.2527/jas2015-9793

62. Resende TP, Medida RL, Vannucci FA, Saqui-Salces M, Gebhart C (2020) Evaluation of swine enteroids as in vitro models for Lawsonia intracellularis infection. J Anim Sci 98:skaa011. https://doi.org/10.1093/jas/skaa0 11

63. Li L, Fu F, Guo S, Wang H, He X, Xue M, Yin L, Feng L, Liu P (2019) Porcine intestinal enteroids: a new model for studying enteric coronavirus porcine epidemic diarrhea virus infection and the host innate response. J Virol 93:e01682. https://doi.org/10.1128/jvi.01682-18

64. Li L, Xue M, Fu F, Yin L, Feng L, Liu P (2019) IFN-Lambda 3 mediates antiviral protection against porcine epidemic diarrhea virus by inducing a distinct antiviral transcript profile in porcine intestinal epithelia. Front Immunol 10:2394. https://doi.org/10.3389/fimmu.2019.02394

65. Zhang J, Guo L, Yang L, Xu J, Zhang L, Feng L, Chen H, Wang Y (2018) Metalloprotease ADAM17 regulates porcine epidemic diarrhea virus infection by modifying aminopeptidase N. Virology 517:24-29. https:// doi.org/10.1016/j.virol.2018.02.001

66. Zeng S, Zhang H, Ding Z, Luo R, An K, Liu L, Bi J, Chen H, Xiao S, Fang $L$ (2015) Proteome analysis of porcine epidemic diarrhea virus (PEDV)infected Vero cells. Proteomics 15:1819-1828. https://doi.org/10.1002/ pmic.201400458

67. Ji C-M, Wang B, Zhou J, Huang Y-W (2018) Aminopeptidase-Nindependent entry of porcine epidemic diarrhea virus into Vero or porcine small intestine epithelial cells. Virology 517:16-23. https://doi. org/10.1016/j.virol.2018.02.019

68. Desmyter J, Melnick JL, Rawls WE (1968) Defectiveness of interferon production and of rubella virus interference in a line of African green monkey kidney cells (Vero). J Virol 2:955-961

69. Zhang Q, Ke H, Blikslager A, Fujita T, Yoo D (2018) Type III interferon restriction by porcine epidemic diarrhea virus and the role of viral protein nsp1 in IRF1 signaling. J Virol 92:e01677. https://doi. org/10.1128/jvi.01677-17

70. Fu F, Li L, Shan L, Yang B, Shi H, Zhang J, Wang H, Feng L, Liu P (2017) A spike-specific whole-porcine antibody isolated from a porcine $B$ cell that neutralizes both genogroup 1 and 2 PEDV strains. Vet Microbiol 205:99-105. https://doi.org/10.1016/j.vetmic.2017.05.013

71. Yin L, Chen J, Li L, Guo S, Xue M, Zhang J, Liu X, Feng L, Liu P (2020) Aminopeptidase $\mathrm{N}$ expression, not interferon responses, determines the intestinal segmental tropism of porcine deltacoronavirus. J Virol 94(14):e00480. https://doi.org/10.1128/JVI.00480-20

72. Luo H, Zheng J, Chen Y, Wang T, Zhang Z, Shan Y, Xu J, Yue M, Fang W, Li X (2020) Utility evaluation of porcine enteroids as PDCoV infection model in vitro. Front Microbiol 11:821

73. Li Y, Yang N, Chen J, Huang X, Zhang N, Yang S, Liu G, Liu G (2020) NextGeneration porcine intestinal organoids: an apical-out organoid model for swine enteric virus infection and immune response investigations. J Virol 94:e01006-e01020. https://doi.org/10.1128/JVI.01006-20

74. Ferrandis Vila M, Trudeau MP, Hung Y-T, Zeng Z, Urriola PE, Shurson GC, Saqui-Salces M (2018) Dietary fiber sources and non-starch polysaccharide-degrading enzymes modify mucin expression and the immune profile of the swine ileum. PLoS ONE 13:e0207196

75. Olayanju A, Jones L, Greco K, Goldring CE, Ansari T (2019) Application of porcine gastrointestinal organoid units as a potential in vitro tool for drug discovery and development. J Appl Toxicol 39:4-15. https://doi. org/10.1002/jat.3641

76. Stieler Stewart A, Freund JM, Blikslager AT, Gonzalez LM (2018) Intestinal stem cell isolation and culture in a porcine model of segmental small intestinal ischemia. J Vis Exp 135:57647. https://doi.org/10.3791/57647

77. Zhu M, Qin YC, Gao CQ, Yan HC, Li XG, Wang XQ (2019) Extracellular glutamate-induced mTORC1 activation via the IR/IRS/PI3K/Akt pathway enhances the expansion of porcine intestinal stem cells. J Agric Food Chem 67:9510-9521. https://doi.org/10.1021/acs.jafc.9b03626

78. Engevik AC, Coutts AW, Kaji I, Rodriguez P, Ongaratto F, Saqui-Salces M, Medida RL, Meyer AR, Kolobova E, Engevik MA, Williams JA, Shub MD, Carlson DF, Melkamu T, Goldenring JR (2020) Editing myosin VB gene to create porcine model of microvillus inclusion disease, with microvilluslined inclusions and alterations in sodium transporters. Gastroenterology 158:2236-2249.e9. https://doi.org/10.1053/j.gastro.2020.02.034

79. Wang $Z$, Li J, Wang $Y$, Wang L, Yin $Y$, Yin L, Yang H, Yin Y (2020) Dietary vitamin $A$ affects growth performance, intestinal development, and functions in weaned piglets by affecting intestinal stem cells. J Anim Sci 98:skaa020. https://doi.org/10.1093/jas/skaa020

80. Li XG, Zhu M, Chen MX, Fan HB, Fu HL, Zhou JY, Zhai ZY, Gao CQ, Yan HC, Wang XQ (2019) Acute exposure to deoxynivalenol inhibits porcine enteroid activity via suppression of the Wnt/beta-catenin pathway. Toxicol Lett 305:19-31. https://doi.org/10.1016/j.toxlet.2019.01.008

81. Zhu M, Qin YC, Gao CQ, Yan HC, Wang XQ (2020) I-Glutamate drives porcine intestinal epithelial renewal by increasing stem cell activity via upregulation of the EGFR-ERK-mTORC1 pathway. Food Funct 11:2714-2724. https://doi.org/10.1039/c9fo03065d

82. Panek M, Grabacka M, Pierzchalska M (2018) The formation of intestinal organoids in a hanging drop culture. Cytotechnology 70:1085-1095. https://doi.org/10.1007/s10616-018-0194-8

83. Pierzchalska M, Panek M, Grabacka M (2018) The migration and fusion events related to ROCK activity strongly influence the morphology of chicken embryo intestinal organoids. Protoplasma 256:575-581. https ://doi.org/10.1007/s00709-018-1312-3

84. Pierzchalska M, Panek M, Czyrnek M, Gielicz A, Mickowska B, Grabacka M (2017) Probiotic Lactobacillus acidophilus bacteria or synthetic TLR2 agonist boost the growth of chicken embryo intestinal organoids in cultures comprising epithelial cells and myofibroblasts. Comp Immunol Microbiol Infect Dis 53:7-18. https://doi.org/10.1016/j.cimid .2017 .06 .002

85. Pierzchalska M, Grabacka M, Michalik M, Zyla K, Pierzchalski P (2012) Prostaglandin E-2 supports growth of chicken embryo intestinal organoids in Matrigel matrix. Biotechniques 52:307-315. https://doi. org/10.2144/0000113851

86. Acharya M, Arsi K, Donoghue AM, Liyanage R, Rath NC (2020) Production and characterization of avian crypt-villus enteroids and the effect of chemicals. BMC Vet Res 16:179. https://doi.org/10.1186/s12917-02002397-1 
87. Li J, Li J, Zhang SY, Li RX, Lin X, Mi YL, Zhang CQ (2018) Culture and characterization of chicken small intestinal crypts. Poult Sci 97:1536-1543. https://doi.org/10.3382/ps/pey010

88. Topfer E, Pasotti A, Telopoulou A, Italiani P, Boraschi D, Ewart MA, Wilde C (2019) Bovine colon organoids: from 3D bioprinting to cryopreserved multi-well screening platforms. Toxicol In Vitro 61:104606. https://doi. org/10.1016/j.tiv.2019.104606

89. Hamilton CA, Young R, Jayaraman S, Sehgal A, Paxton E, Thomson S, Katzer F, Hope J, Innes E, Morrison LJ, Mabbott NA (2018) Development of in vitro enteroids derived from bovine small intestinal crypts. Vet Res 49:54. https://doi.org/10.1186/s13567-018-0547-5

90. Liu M, Yu W, Jin J, Ma M, An T, Nie Y, Teng CB (2020) Copper promotes sheep pancreatic duct organoid growth by activation of an antioxidant protein 1-dependent MEK-ERK pathway. Am J Physiol Cell Physiol 318:C806-C816. https://doi.org/10.1152/ajpcell.00509.2019

91. Chandra L, Borcherding DC, Kingsbury D, Atherly T, Ambrosini YM, Bourgois-Mochel A, Yuan W, Kimber M, Qi Y, Wang Q, Wannemuehler M, Ellinwood NM, Snella E, Martin M, Skala M, Meyerholz D, Estes M, Fernandez-Zapico ME, Jergens AE, Mochel JP, Allenspach K (2019) Derivation of adult canine intestinal organoids for translational research in gastroenterology. BMC Biol 17:33. https://doi.org/10.1186/s1291 5-019-0652-6

92. Gelberg HB (2014) Comparative anatomy, physiology, and mechanisms of disease production of the esophagus, stomach, and small intestine. Toxicol Pathol 42:54-66. https://doi.org/10.1177/0192623313518113

93. Wiener DJ, Basak O, Asra P, Boonekamp KE, Kretzschmar K, Papaspyropoulos A, Clevers H (2018) Establishment and characterization of a canine keratinocyte organoid culture system. Vet Dermatol 29:375. https://doi.org/10.1111/vde.12541

94. Kruitwagen HS, Spee B, Viebahn CS, Venema HB, Penning LC, Grinwis GC, Favier RP, van den Ingh TS, Rothuizen J, Schotanus BA (2014) The canine hepatic progenitor cell niche: molecular characterisation in health and disease. Vet J 201:345-352. https://doi.org/10.1016/j. tvjl.2014.05.024

95. Spee B, Carpino G, Schotanus BA, Katoonizadeh A, Vander Borght S, Gaudio E, Roskams T (2010) Characterisation of the liver progenitor cell niche in liver diseases: potential involvement of Wnt and Notch signalling. Gut 59:247-257. https://doi.org/10.1136/gut.2009.188367

96. Nantasanti S, Spee B, Kruitwagen HS, Chen C, Geijsen N, Oosterhoff LA, van Wolferen ME, Pelaez N, Fieten H, Wubbolts RW, Grinwis GC, Chan J, Huch M, Vries RRG, Clevers H, de Bruin A, Rothuizen J, Penning LC, Schotanus BA (2015) Disease modeling and gene therapy of copper storage disease in canine hepatic organoids. Stem Cell Reports 5:895-907. https ://doi.org/10.1016/j.stemcr.2015.09.002

97. Chen TC, Neupane M, Chien SJ, Chuang FR, Crawford RB, Kaminski NE, Chang CC (2019) Characterization of adult canine kidney epithelial stem cells that give rise to dome-forming tubular cells. Stem Cells Dev 28:1424-1433. https://doi.org/10.1089/scd.2019.0049

98. Usui T, Sakurai M, Nishikawa S, Umata K, Nemoto Y, Haraguchi T, Itamoto K, Mizuno T, Noguchi S, Mori T, Iwai S, Nakagawa T, Yamawaki H, Ohama T, Sato K (2017) Establishment of a dog primary prostate cancer organoid using the urine cancer stem cells. Cancer Sci 108:2383-2392. https ://doi.org/10.1111/cas.13418

99. Elbadawy M, Usui T, Mori T, Tsunedomi R, Hazama S, Nabeta R, Uchide T, Fukushima R, Yoshida T, Shibutani M, Tanaka T, Masuda S, Okada R, Ichikawa R, Omatsu T, Mizutani T, Katayama Y, Noguchi S, Iwai S, Nakagawa T, Shinohara Y, Kaneda M, Yamawaki H, Sasaki K (2019) Establishment of a novel experimental model for muscle-invasive bladder cancer using a dog bladder cancer organoid culture. Cancer Sci 110:2806-2821. https ://doi.org/10.1111/cas.14118

100. Tekes G, Ehmann R, Boulant SA-O, Stanifer MA-O (2020) Development of feline ileum- and colon-derived organoids and their potential use to support feline coronavirus infection. Cells 9:2085

101. Kruitwagen HS, Oosterhoff LA, Vernooij I, Schrall IM, van Wolferen ME, Bannink F, Roesch C, van Uden L, Molenaar MR, Helms JB, Grinwis GCM, Verstegen MMA, van der Laan LJW, Huch M, Geijsen N, Vries RG, Clevers H, Rothuizen J, Schotanus BA, Penning LC, Spee B (2017) Long-term adult feline liver organoid cultures for disease modeling of hepatic steatosis. Stem Cell Reports 8:822-830. https://doi.org/10.1016/j.stemc r.2017.02.015
102. Haaker MW, Kruitwagen HS, Vaandrager AB, Houweling M, Penning LC, Molenaar MR, van Wolferen ME, Oosterhoff LA, Spee B, Helms JB (2020) Identification of potential drugs for treatment of hepatic lipidosis in cats using an in vitro feline liver organoid system. J Vet Intern Med 34:132-138. https://doi.org/10.1111/jvim.15670

103. Stewart AS, Freund JM, Gonzalez LM (2018) Advanced three-dimensional culture of equine intestinal epithelial stem cells. Equine Vet J 50:241-248. https://doi.org/10.1111/evj.12734

104. Mussard E, Pouzet C, Helies V, Pascal G, Fourre S, Cherbuy C, Rubio A, Vergnolle N, Combes S, Beaumont M (2020) Culture of rabbit caecum organoids by reconstituting the intestinal stem cell niche in vitro with pharmacological inhibitors or L-WRN conditioned medium. Stem Cell Res 48:101980. https://doi.org/10.1016/.scr.2020.101980

105. Langan LM, Owen SF, Jha AN (2018) Establishment and long-term maintenance of primary intestinal epithelial cells cultured from the rainbow trout. Oncorhynchus mykiss. Biol Open 7:bio032870. https:// doi.org/10.1242/bio.032870

106. Hughes CS, Postovit LM, Lajoie GA (2010) Matrigel: a complex protein mixture required for optimal growth of cell culture. Proteomics 10:1886-1890. https://doi.org/10.1002/pmic.200900758

107. Gjorevski N, Lutolf MP (2017) Synthesis and characterization of well-defined hydrogel matrices and their application to intestinal stem cell and organoid culture. Nat Protoc 12:2263-2274. https://doi. org/10.1038/nprot.2017.095

108. Lutolf MP, Gilbert PM, Blau HM (2009) Designing materials to direct stem-cell fate. Nature 462:433-441. https://doi.org/10.1038/nature0860 2

109. Kratochvil MJ, Seymour AJ, Li TL, Paşca SP, Kuo CJ, Heilshorn SC (2019) Engineered materials for organoid systems. Nat Rev Materials 4:606-622. https://doi.org/10.1038/s41578-019-0129-9

110. Foulke-Abel J, In J, Kovbasnjuk O, Zachos NC, Ettayebi K, Blutt SE, Hyser JM, Zeng XL, Crawford SE, Broughman JR, Estes MK, Donowitz M (2014) Human enteroids as an ex vivo model of host-pathogen interactions in the gastrointestinal tract. Exp Biol Med (Maywood) 239:1124-1134. https://doi.org/10.1177/1535370214529398

111. Thorne CA, Chen IW, Sanman LE, Cobb MH, Wu LF, Altschuler SJ (2018) Enteroid monolayers reveal an autonomous WNT and BMP circuit controlling intestinal epithelial growth and organization. Dev Cell 44:624-633.e4. https://doi.org/10.1016/j.devcel.2018.01.024

112. Kar SK, van der Hee B, Loonen LMP, Taverne N, Taverne-Thiele JJ, Schokker D, Smits MA, Jansman AJM, Wells JM (2020) Effects of undigested protein-rich ingredients on polarised small intestinal organoid monolayers. J Anim Sci Biotechnol 11:51. https://doi.org/10.1186/s4010 4-020-00443-4

113. Liu Y, Chen Y-G (2018) 2D- and 3D-based intestinal stem cell cultures for personalized medicine. Cells 7:225. https://doi.org/10.3390/cells71202 25

114. Braverman J, Yilmaz ÖH (2018) From 3D organoids back to 2D enteroids. Dev Cell 44:533-534. https://doi.org/10.1016/j.devcel.2018.02.016

115. Callesen MM, Arnadottir SS, Lyskjaer I, Orntoft M-BW, Hoyer S, Dagnaes-Hansen F, Liu Y, Li R, Callesen H, Rasmussen MH, Berthelsen MF, Thomsen MK, Schweiger PJ, Jensen KB, Laurberg S, Orntoft TF, Elverlov-Jakobsen JE, Andersen CL (2017) A genetically inducible porcine model of intestinal cancer. Mol Oncol 11:1616-1629. https://doi. org/10.1002/1878-0261.12136

116. Schutgens F, Rookmaaker MB, Margaritis T, Rios A, Ammerlaan C, Jansen J, Gijzen L, Vormann M, Vonk A, Viveen M, Yengej FY, Derakhshan S, de Winter-de Groot KM, Artegiani B, van Boxtel R, Cuppen E, Hendrickx APA, van den Heuvel-Eibrink MM, Heitzer E, Lanz H, Beekman J, Murk J-L, Masereeuw R, Holstege F, Drost J, Verhaar MC, Clevers H (2019) Tubuloids derived from human adult kidney and urine for personalized disease modeling. Nat Biotechnol 37:303-313. https://doi.org/10.1038/ s41587-019-0048-8

117. Zietek T, Giesbertz $P$, Ewers $M$, Reichart $F$, Weinmüller M, Urbauer E, Haller D, Demir IE, Ceyhan GO, Kessler H, Rath E (2020) Organoids to study intestinal nutrient transport, drug uptake and metabolismupdate to the human model and expansion of applications. Front Bioeng Biotechnol 8:577656

118. Deusser H, Rogoll D, Scheppach W, Volk A, Melcher R, Richling E (2013) Gastrointestinal absorption and metabolism of apple 
polyphenols ex vivo by the pig intestinal mucosa in the Ussing chamber. Biotechnol J 8:363-370. https://doi.org/10.1002/biot.20120 0303

119. Yen JT, Kerr BJ, Easter RA, Parkhurst AM (2004) Difference in rates of net portal absorption between crystalline and protein-bound lysine and threonine in growing pigs fed once daily. J Anim Sci 82:1079_ 1090. https://doi.org/10.2527/2004.8241079x

120. Rikkers RSC, Madsen O, Wells JM, Taverne N, Taverne-Thiele AJ, WoeIders H, Kar SK, Bergsma R, Ellen ED (2020) Transcriptomic analysis of pig intestinal organoids divergent for $\mathrm{FE}$ and their response to $E$. coli. In: European Federation of Animal Science (EAAP) 2020, Virtual meeting, Wageningen Academic Publishers, p 349

121. Barkauskas CE, Chung M-I, Fioret B, Gao X, Katsura H, Hogan BLM (2017) Lung organoids: current uses and future promise. Development 144:986-997. https://doi.org/10.1242/dev.140103

122. Srivastava V, Huycke TR, Phong KT, Gartner ZJ (2020) Organoid mod els for mammary gland dynamics and breast cancer. Curr Opin Cell Biol 66:51-58. https://doi.org/10.1016/j.ceb.2020.05.003

123. Llewellyn A, Foey A (2017) Probiotic modulation of innate cell pathogen sensing and signaling events. Nutrients 9:1156. https://doi. org/10.3390/nu9101156

124. Rossi O, van Baarlen P, Wells JM (2013) Host-recognition of pathogens and commensals in the mammalian intestine. Curr Top Microbiol Immunol 358:291-321. https://doi.org/10.1007/82_2011_191

125. Jones LG, Vaida A, Thompson LM, Ikuomola FI, Caamaño JH, Burkitt MD, Miyajima F, Williams JM, Campbell BJ, Pritchard DM, Duckworth CA (2019) NF-KB2 signalling in enteroids modulates enterocyte responses to secreted factors from bone marrow-derived dendritic cells. Cell Death Dis 10(12):896. https://doi.org/10.1038/s4141 9-019-2129-5

126. Wosen JE, Ilstad-Minnihan A, Co JY, Jiang W, Mukhopadhyay D, Fernandez-Becker NQ, Kuo CJ, Amieva MR, Mellins ED (2019) Human intestinal enteroids model MHC-II in the gut epithelium. Front Immunol 10:1970

127. Kraiczy J, Nayak K, Ross A, Raine T, MakTN, Gasparetto M, Cario E, Rakyan V, Heuschkel R, Zilbauer M (2016) Assessing DNA methylation in the developing human intestinal epithelium: potential link to inflammatory bowel disease. Mucosal Immunol 9:647-658. https://doi. org/10.1038/mi.2015.88

128. Herman JG, Baylin SB (2003) Gene silencing in cancer in association with promoter hypermethylation. N Engl J Med 349:2042-2054. https:// doi.org/10.1056/NEJMra023075

129. Kraiczy J, Zilbauer M (2019) Intestinal epithelial organoids as tools to study epigenetics in gut health and disease. Stem Cells Int 2019:7242415. https://doi.org/10.1155/2019/7242415

130. Lewis SK, Nachun D, Martin MG, Horvath S, Coppola G, Jones DL (2020) DNA methylation analysis validates organoids as a viable model for studying human intestinal aging. Cell Mol Gastroenterol Hepatol 9:527-541. https://doi.org/10.1016/j.jcmgh.2019.11.013

131. Joshi R, Castro De Moura M, Piñeyro D, Alvarez-Errico D, Arribas C, Esteller M (2020) The DNA methylation landscape of human cancer organoids available at the American type culture collection. Epigenetics 15:1167-1177. https://doi.org/10.1080/15592294.2020.1762398

132. Rubio LA (2019) Possibilities of early life programming in broiler chickens via intestinal microbiota modulation. Poult Sci 98:695-706. https:// doi.org/10.3382/ps/pey416

133. Ji Y, Wu Z, Dai Z, Wang X, Li J, Wang B, Wu G (2017) Fetal and neonatal programming of postnatal growth and feed efficiency in swine. J Anim Sci Biotechnol 8:42. https://doi.org/10.1186/s40104-017-0173-5

134. Kar SK, Jansman AJM, Boeren S, Kruijt L, Smits MA (2016) Protein, peptide, amino acid composition, and potential functional properties of existing and novel dietary protein sources for monogastrics. J Anim Sci 94:30-39. https://doi.org/10.2527/jas.2015-9677

135. Rosch C, Taverne N, Venema K, Gruppen H, Wells JM, Schols HA (2017) Effects of in vitro fermentation of barley beta-glucan and sugar beet pectin using human fecal inocula on cytokine expression by dendritic cells. Mol Nutr Food Res 61:1600243. https://doi.org/10.1002/ mnfr.201600243

136. Jansman AJM (2016) Health and functions of the gastrointestinal tract in pigs: effects of functional ingredients and feed and ingredient processing. J Anim Sci 94:12-21. https://doi.org/10.2527/jas.2015-9886
137. Goddard ME, Hayes BJ (2009) Mapping genes for complex traits in domestic animals and their use in breeding programmes. Nat Rev Genet 10:381-391. https://doi.org/10.1038/nrg2575

138. Meuwissen TH, Hayes BJ, Goddard ME (2001) Prediction of total genetic value using genome-wide dense marker maps. Genetics 157:1819-1829

139. Knol EF, Nielsen B, Knap PW (2016) Genomic selection in commercial pig breeding. Anim Front 6:15-22. https://doi.org/10.2527/af.2016-0003

140. Harlizius B, Mathur P, Knol EF (2020) Breeding for resilience: new opportunities in a modern pig breeding program. J Anim Sci 98:S150-S154. https://doi.org/10.1093/jas/skaa141

141. Veerkamp R (2013) Selection on feed intake or feed efficiency: A position paper from gDMl breeding goal discussions. In: Interbull meeting 2013, vol 47. Open Journal Systems (OJS)

142. Augustyniak J, Bertero A, Coccini T, Baderna D, Buzanska L, Caloni F (2019) Organoids are promising tools for species-specific in vitro toxicological studies. J Appl Toxicol 39:1610-1622. https://doi.org/10.1002/ jat.3815

143. Park S-H, Moon Y (2020) Enterocyte-based bioassay via quantitative combination of proinflammatory sentinels specific to 8-ketotrichothecenes. Front Immunol 11:1530

144. Forsythe SD, Devarasetty M, Shupe T, Bishop C, Atala A, Soker S, Skardal A (2018) Environmental toxin screening using human-derived 3D bioengineered liver and cardiac organoids. Front Public Health 6:103

145. Sala FG, Kunisaki SM, Ochoa ER, Vacanti J, Grikscheit TC (2009) Tissueengineered small intestine and stomach form from autologous tissue in a preclinical large animal model. J Surg Res 156:205-212. https://doi. org/10.1016/j.jss.2009.03.062

146. Miyazawa M, Torii T, Toshimitsu Y, Okada K, Koyama I, Ikada Y (2005) A tissue-engineered artificial bile duct grown to resemble the native bile duct. Am J Transplant 5:1541-1547. https://doi.org/10.111 1/j.1600-6143.2005.00845.x

147. Elçin YM, Dixit V, Lewin K, Gitnick G (1999) Xenotransplantation of fetal porcine hepatocytes in rats using a tissue engineering approach. Artif Organs 23:146-152. https://doi.org/10.1046/j.1525-1594.1999.06222.x

148. Funatsu K, ljima H, Nakazawa K, Yamashita Y, Shimada M, Sugimachi K (2001) Hybrid artificial liver using hepatocyte organoid culture. Artif Organs 25:194-200. https://doi.org/10.1046/j.1525-1594.2001.02500 3194.x

149. Mizumoto H, Funatsu K (2004) Liver regeneration using a hybrid artificial liver support system. Artif Organs 28(1):53-57. https://doi.org/10.11 11/j.1525-1594.2004.07326.x

150. Hochleitner B, Hengster P, Duo L, Bucher H, Klima G, Margreiter R (2005) A novel bioartificial liver with culture of porcine hepatocyte aggregates under simulated microgravity. Artif Organs 29:58-66. https://doi.org/10. 1111/j.1525-1594.2004.29014.x

151. Ishii Y, Saito R, Marushima H, Ito R, Sakamoto T, Yanaga K (2008) Hepatic reconstruction from fetal porcine liver cells using a radial flow bioreactor. World J Gastroenterol 14:2740-2747. https://doi.org/10.3748/ wjg. 14.2740

152. Janssen DAW, Geutjes PJ, Odenthal J, van Kuppevelt TH, Schalken JA, Feitz WFJ, Heesakkers J (2013) A new, straightforward ex vivo organoid bladder mucosal model for preclinical research. J Urol 190:341-349. https://doi.org/10.1016/j.juro.2012.12.103

153. Mingone CJ, Gupte SA, Chow JL, Ahmad M, Abraham NG, Wolin MS (2006) Protoporphyrin IX generation from delta-aminolevulinic acid elicits pulmonary artery relaxation and soluble guanylate cyclase activation. Am J Physiol Lung Cell Mol Physiol 291:L337-L344. https:// doi.org/10.1152/ajplung.00482.2005

154. Neo BH, Kandhi S, Wolin MS (2010) Roles for soluble guanylate cyclase and a thiol oxidation-elicited subunit dimerization of protein kinase $\mathrm{G}$ in pulmonary artery relaxation to hydrogen peroxide. Am J Physiol Heart Circ Physiol 299:H1235-H1241. https://doi.org/10.1152/ajphe art.00513.2010

155. Neo BH, Kandhi S, Wolin MS (2011) Roles for redox mechanisms controlling protein kinase $\mathrm{G}$ in pulmonary and coronary artery responses to hypoxia. Am J Physiol Heart Circ Physiol 301:H2295-H2304. https://doi. org/10.1152/ajpheart.00624.2011

156. Patel D, Alhawaj R, Kelly MR, Accarino JJO, Lakhkar A, Gupte SA, Sun D, Wolin MS (2016) Potential role of mitochondrial superoxide decreasing ferrochelatase and heme in coronary artery soluble guanylate cyclase 
depletion by angiotensin II. Am J Physiol Heart Circ Physiol 310:H1439H1447. https://doi.org/10.1152/ajpheart.00859.2015

157. Kandhi S, Neo BH, Wolin M (2011) Organoid culture of bovine coronary arteries reverses the response to hypoxia from relaxation to contraction associated with alterations in mechanisms controlling protein kinase G. Faseb J 25:1102

158. Irie Y, Mizumoto H, Fujino S, Kajiwara T (2008) Development of articular cartilage grafts using organoid formation techniques. Transplant Proc 40:631-633. https://doi.org/10.1016/j.transproceed.2008.01.024

159. Mizuno S, Takada E, Fukai N (2015) Spheroidal organoids reproduce characteristics of longitudinal depth zones in bovine articular cartilage. Cells Tissues Organs 202:382-392. https://doi.org/10.1159/000447532

160. Rusu D, Loret S, Peulen O, Mainil J, Dandrifosse G (2005) Immunochemical, biomolecular and biochemical characterization of bovine epithelial intestinal primocultures. BMC Cell Biol 6:42. https://doi. org/10.1186/1471-2121-6-42

161. Podbesek R, Hamilton JW, Macgregor RR (1984) Calcium responsive organoid cultures of bovine parathyroid cells. Calcified Tissue Int 36:506-506

162. Ridgeway RD, Hamilton JW, MacGregor RR (1986) Characteristics of bovine parathyroid cell organoids in culture. Vitro Cell Dev Biol 22:91-99. https://doi.org/10.1007/bf02623538

163. Bansal DD, Macgregor RR (1990) Secretion of plasminogen activator from bovine parathyroid cells. Endocrinology 126:2245-2251. https:// doi.org/10.1210/endo-126-5-2245
164. Hinton DA, Bansal DD, Macgregor RR (1994) Effects of insulin and calcium on parathyroid-hormone gene-transcription in bovine parathyroid organoids. Endocrine 2:411-417

165. Ritter CS, Slatopolsky E, Santoro S, Brown AJ (2004) Parathyroid cells cultured in collagen matrix retain calcium responsiveness: importance of three-dimensional tissue architecture. J Bone Miner Res 19:491-498. https://doi.org/10.1359/jbmr.2004.19.3.491

166. Ritter CS, Pande S, Krits I, Slatopolsky E, Brown AJ (2008) Destabilization of parathyroid hormone mRNA by extracellular $\mathrm{Ca} 2+$ and the calcimimetic R-568 in parathyroid cells: role of cytosolic Ca and requirement for gene transcription. J Mol Endocrinol 40:13-21. https://doi. org/10.1677/jme-07-0085

167. Agopian VG, Chen DC, Avansino JR, Stelzner M (2009) Intestinal stem cell organoid transplantation generates neomucosa in dogs. J Gastrointest Surg 13:971-982. https://doi.org/10.1007/s11605-009-0806-x

\section{Publisher's Note}

Springer Nature remains neutral with regard to jurisdictional claims in published maps and institutional affiliations.
Ready to submit your research? Choose BMC and benefit from:

- fast, convenient online submission

- thorough peer review by experienced researchers in your field

- rapid publication on acceptance

- support for research data, including large and complex data types

- gold Open Access which fosters wider collaboration and increased citations

- maximum visibility for your research: over 100M website views per year

At BMC, research is always in progress.

Learn more biomedcentral.com/submissions 